\title{
Explorations of Beliefs about EFL Teachers' Roles from Both Teachers' and Students' Perspectives through Metaphor Analysis
}

\author{
Sharihan Shawkat Azeez, MA \\ Dept. of English, College of Languages, \\ University of Duhok, Kurdistan Region, Iraq
}

Doi:10.19044/esj.2020.v16n29p205 URL:http://dx.doi.org/10.19044/esj.2020.v16n29p205

\begin{abstract}
Metaphor acts as a window into comprehending teachers' experiences through providing insights into complex concepts of teaching and learning. As a result, it plays a crucial role in exploring beliefs about teachers' roles in the teaching and learning process. To elicit ideas and beliefs which both teachers and students held about the role of English teachers, questionnaires were given to 30 teachers and 85 students in the University of Duhok, English Department. The questionnaire asked the subjects to provide their beliefs about English teachers' roles by using a sentence completion task "An English teacher is.... because....". Eight conceptual categories are introduced from the linguistic metaphors and example metaphors for each category are given in the results tables. The eight conceptual categories include: teacher as devotee, teacher as nurturer, teachers as provider / source of knowledge, teacher as cultural transmitter, teacher as authority, teacher as guider, teacher as a friend, and teacher as a nice beautiful soul. All participants expressed the same conceptual categories, but still they use different metaphors to express their views. An interesting feature of these results is that there are some parallel and overlaps of metaphors among different subjects. The findings of this study suggested subtle differences between students' and teachers' beliefs. This study will benefit teachers, curriculum designers, and researchers. Researchers may carry out comprehensive studies using metaphor as an investigating tool to better understand both students and teachers' perceptions of the teachers' roles. The results will help develop comprehensive and inclusive methods of teaching. Larger samples with variables such as gender, age, different locations, and proficiency of participants should be taken into consideration during future studies.
\end{abstract}

Keywords: Conceptual Metaphor Theory (CMT), Metaphor, teaching and learning process, cognitive tool, role of language teachers 


\section{Introduction}

A metaphor is a term derived from the Greek word 'metaphorian' meaning 'transference.' It is a figure of speech in which a word or phrase is used beyond its literal meaning to describe and understand something else (McGlone, 2007). However, metaphor has been identified by different scholars. For example, Aristotle (1965) admitted that metaphor is proof of the mysteriousness of language and its genius, but he also perceived it as an ornamental device which is appropriate for poetry but too obscure for philosophical or scientific discourse. His understanding of metaphor is known as the Aristotelian comparison view in which he stated that the metaphor of the form $\mathrm{X}$ which is $\mathrm{Y}$ can be understood explicitly by converting it into simile ( $\mathrm{X}$ is like $\mathrm{Y}$ ). Thus, metaphor use and comprehension depend on finding similarities between the two forms. In the twentieth century, the study of metaphor witnessed a significant change. After being the interest of literary scholars, who focused on studying metaphor by interpreting particular tropes in poetry and fiction, it became a significant linguistic device. Richard (1936) defined metaphor as comparing one term to another one to describe it. He suggested a new approach in understanding metaphor in which he introduces the following terms: vehicle- the term used metaphorically, 'tenor' or 'topic' - the term to which it is applied, and the ground (the meaning of metaphor). Black (1962, as cited in McGlone, 2007) rejected the traditional Aristotelian view of metaphor and came out with his Interaction View in which he argued that metaphor is a communicative approach operating at the level of conceptual structure rather than mere words. His Interaction View has been preferred by many contemporary metaphor theorists, and a variety of theories and models have been introduced to explain how topic and vehicle concepts interact to create a metaphoric meaning. However, the most significant one is the Conceptual Theory of metaphor suggested by Lakoff and Johnson (1980). They claim that conceptual metaphors are based on human cognition (how the human body and brain function in relation to the environment). In other words, a metaphor should be thought of as a method of mapping or mental connection from one domain of experience (the source domain) to another (the target domain). Typically, target domains are more concrete. Thus, one can define a conceptual metaphor as understanding one abstract object in terms of a concrete or less abstract one (Kovecses, 2002). Therefore, this paper adopts this theory because according to Lakoff et al. (1980), they foregrounded the conceptual metaphor as something structured, analyzable, and connected with nature and everyday reasoning. Thus, conceptual metaphors represent ways of thinking in which people conceptualize abstract concepts such as time, emotions, arguments, and ideas in terms of more easily understood and concrete ones such as places, objects, and substances. If this is the case, then one can argue that with Conceptual Metaphor Theory (CMT), we could go 
farther in investigating the way people think of, and perceive, things and people in the world they experience.

\section{Metaphor as an Investigating Tool}

It has been shown that metaphor plays a vital role in education as a cognitive tool in revealing and reflecting social thoughts and practices in schooling, and it has a great share in the development of a number of disciplines. Thus, one can assume that a metaphor can perform various functions. However, its function as a tool to explore teachers' and learners' beliefs, raise their awareness of key concepts, models and issues, and to help teachers to reflect on their own experiences and to develop professionally has been used widely by different scholars (Cortazzi \& Jin, 1999).

Wertsh (1991) encouraged the idea of dealing with the intellectual process through some mediating psychological tools as metaphor. The view of metaphors as mediating psychological tools corresponds with Lakoff et al. (1980) approach to metaphor as cognition in which they viewed metaphors as a way of knowing and thinking when using the language. Gibbs (1994, as cited in Villamil \& de Guerreo, 2005) described metaphors as an excellent tool for understanding and comprehending what is difficult to be understood in terms of nature and experiences. Moreover, metaphors shape the way we perceive our world by consistently linking one mental domain to another. Thus, one can argue that metaphors play a critical role in revealing beliefs in different fields of knowledge. Accordingly, educational researchers have been encouraged to use metaphor as a research tool to dive deeply in knowing people's cognition and 'bringing assumption to awareness, encouraging reflection, finding contractions, and fostering change in educational beliefs and practices' (Villamil et al., 2005). For example, Cameron and Low (1999) investigated teachers' cognition. Moreover, in their study, Villamil et al. (2005) used metaphor as the chief mediator in the formation and reformation of notions on writing and it has a significant impact on students' belief systems. Participants were asked to create metaphors about the teaching of writings, analyze their assumptions and beliefs, and to express their views about the impact of metaphor on their conceptualization of writing. The outcomes that metaphor conceptualization achieved in their study (a) helped the participants to clarify their ideas about the process of writing, (b) see new dimensions of the ESL writing classroom, and (c) offered personal growth through sharing different views and as a consequence of changing their own concepts of teaching and learning, writing, and enabling them to have their own voice and roles.

Also, researchers in the field of teacher education have shown that metaphor plays a crucial role in revealing fundamental beliefs about teaching and studying important aspects of teachers' cognition, for instance, how teachers plan, make decisions, or relate to their experiences (Munby, 1986). 
Ellis and Barkhuize (2005) stated in their book, which is dedicated to metaphor analysis, that metaphors can be used by L2 or second language learners when talking about how their learning can shed light on the way they perceive the language they learn, obstacles, difficulties they encounter when learning, and the process of learning itself. Additionally, metaphors help in investigating the beliefs, feelings, and cognitions of learners. Munby (1986) posited that focusing on the metaphors that teachers use when expressing themselves can be fruitful because they may reflect teachers thinking, their provisional ideas, attitudes, and practices. Moreover, metaphors can act as a gate to the comprehension of teachers' personal experiences (Lin, Shein \& Yang, 2012).

\section{Literature Review}

In the related literature, there are number of studies conducted by researchers on using metaphor as an investigative tool in language teaching and learning. Such studies revealed significant findings related to metaphors in language education for both teachers and students. A number of studies attempted to conceptualize the process of teaching and the role of language teachers (Nikitina \& Furuoka, 2008; Koroglu \& Ekici , 2016; Xiong, Li \& Qu , 2015; Wan, Low \& Li , 2011; Eraslan \& Asmali, 2017; Akbari, 2013; Saban , Kocbeker, \& Saban , 2007). According to the study of Nikitina et al. (2008), the most common metaphors used to describe language teachers were team member, boss, interactor, provider, advisor, and precise mechanism. They concluded that the interaction modes between the teachers and students play a key role in the students' perceptions of their language teachers. Xiong et al. (2015) conducted a study to investigate cognitive thinking or models constructed by groups of Chinese university teachers in the specific context of EFL teaching in China. The findings showed that most of the teachers used journey, building, and conduit metaphors to understand the roles of English as a foreign language (EFL) teachers. Their definitions for EFL teacher were constructed by converging cognitive models, instructor model, transmitter model, and builder model. Saban et al. (2007, p. 133-134) examined metaphors produced by 1142 teacher education students enrolled in three different academic programs in the Faculty of Education of the Selcuk University in Turkey. 64 valid personal metaphors were analyzed and 10 main conceptual themes were identified. The findings suggested that

"while metaphors can act as basic mental models for organizing our knowledge of the world, some complex and abstract ideas require many different metaphors to represent them fully. For example, teaching can be metaphorically described as transmission of knowledge, but it can also be viewed as shaping students into a prescribed mold or facilitation of student learning and understanding. The wide 
range of metaphorical images in our study reveals multiple realities of a "teacher" and no single metaphor that can best capture all of the complexities of teaching."

Another study was carried out by Wan et al. (2011, p.410) to examine the construction of personal 'teacher' metaphors by Chinese university teachers and their English major students to represent beliefs about EFL teachers' roles. Teachers' metaphors were categorized under eight categories named teacher as provider, nurturer, devotee, instructor, culture transmitter, authority, interest arouser, and coworker. The findings identified 'mismatches between students and teachers' beliefs about the teachers' roles, and that, though not seriously opposed to each other, they could nevertheless cause problems'. Akbari (2013) elicited metaphorical expressions from 187 Iranian bilingual (Kurdish-Persian) university students to examine whether they fit into the design of the language teaching and learning approaches and methods. Metaphorical expressions used by the Iranian students were sorted into nine metaphorical categories which included guide, professional, devil, angel, parent natural element, machine, creator, and wet blanket. The three most common metaphorical categories produced by the Iranian students about the EFI teachers' roles included EFL teacher as a guide, EFL teacher as a professional, and EFL teacher as a devil. The results revealed that the imagery used by the Iranian students were comparatively for and against several proposed models of language learning and teaching about EFL teachers' roles. Koroglu et al. (2016) conducted a qualitative study to investigate the perception of 128 English language teacher candidates, who were at their first years at the English Language Teaching Department of Gazi University, on the roles of English language teachers. The study showed that future language teachers had positive perceptions about foreign language teachers. Teachers were perceived as multifunctional with sources of knowledge, culture transmitter, and are considered as a caring person.

Marchants (1992) identified eight generic metaphors which mostly convey the meaning of leadership using metaphor as a cognitive tool to understand teachers' prospective of teachers' roles. For example, teachers are viewed as an authority (judge, police, officer, prison, and warden), caregiver (parent, doctor), director (movie director, orchestra, and conductor), captive (prisoner), person on trial (in a courtroom, awaiting the verdict of a jury), referee and an agent of change (advocate of change). In a similar vein, Cortazzi et al. (1999) in their cross cultural study of Chinese, Japanese, Lebanese, and Turkish teachers identified several metaphors of dominance in which a teacher was compared to a parent, friend, source of knowledge, and guide. The similarity of metaphors across cultures may indicate the fact that the way teachers are viewed in the process of teaching and learning can go beyond 
cultural boundaries. However, this does not exclude the fact that there are some differences in the use of teacher metaphors, which are bound to the differences in cultural backgrounds. As stated by Cameron and Deignan (2006) and Kovecses (2005), metaphor is a way of thinking and experiencing the world. In other words, metaphor translates our cultural experiences and is learned through the interaction and communication within specific sociocultural groups. For example, in their study, Lin et al. (2012) showed that the concepts of 'teacher' are generally different from those identified in Western cultural contexts. They assume that such differences are due to the deep-rooted Confucianism in which symmetrical power relationships between the teacher and students have been the norms.

\section{Aims of the Study}

The inspiration of this study comes from the studies of both Wan et al. (2011) and Saban et al. (2007) and the Conceptual Theory of Metaphor (CTM) which assumes that much of our thoughts and experiences are metaphorically structured (Lakoff et al., 1980). Since metaphors play a crucial role in structuring our cognition and behavior and shaping people's thinking and learning, the researcher sets out to study the metaphors that EFL teachers and students hold about the role of EFL teachers in the process of teaching and learning following Wan et al. (2011) and Saban et al. (2007) studies. Feedback based on metaphors produced by participants will help to raise teachers' awareness about their roles and functions in their future classroom teaching and professional development. Thus, when teachers and students are aware of each others' beliefs, changes in behaviour and attitudes may occur. For example, teachers may adjust the materials, activities, relationships, and behaviour according to the results of both parties' beliefs and understanding, and they may also develop their methodology and style of teaching accordingly. This study will outline how a group of English Department teachers and their students use personal "teacher metaphors" by a metaphor prompt "An English teacher is ...because...." to achieve one of the following aims of the study to:

1. Identify teachers' and students' beliefs about EFL teachers' roles.

2. To help teachers to develop their methodology and style of teaching by introducing them to their students' beliefs and as a consequence develop the preferred pedagogical approaches to be delivered by teachers for students. 


\section{Research Questions}

This research seeks to answer the following two questions:

1. What types of metaphors do Kurdish EFL teachers and students use to refer to the role of EFL teachers in the process of teaching and learning?

2. In what ways do the metaphor conceptualizations of EFL teachers differ between students and their teachers?

\section{Methodology \\ 6.1 Participants}

The study was conducted in the English Department at the University of Duhok. All teaching staff from the English Department were requested to complete the Metaphor Prompt Form. Out of the 30 instructors, 18 completed the Metaphor Prompt Form within the specified timeframe. The research sought to assess students at the beginning and end of the bachelor's education. The researcher decided that second year students were better suited to participate in this study. This is because many first year students lacked the understanding of literary metaphors and sufficient English language vocabulary. Fourth year students were well suited to participate in the study since they had a superior understanding of English and literary metaphors. Additionally, fourth year students would have broad experiences with different teaching staff, approaches, and disciplines. Ultimately, 45 second year students completed the Metaphor Prompt Form while 30 fourth year students completed the Metaphor Prompt Form. The total number of respondents was sufficient for the scope of this investigation.

\subsection{Data Collection}

Instead of directly asking learners about their beliefs, the researcher asked for concrete comparisons using personal 'teacher metaphors' using a metaphor prompt "An English teacher is ...because....". This study adopts questionnaire used by Wan et al. (2011). The advantage of enquiring into learners' thoughts and beliefs through less explicit means is that the findings are more likely to be authentic and reveal beliefs and values that students conceptualize (Block, 1992; McGrath, 2006). The written instructions were clearly worded in English; they were also explained orally when the questionnaire was given to each respondent after attending a metaphor-related seminar. There was a clear understanding to what he/she is expected to do. The questionnaires were handed to respondents during the seminar in person by the researcher. Some teachers responded and returned the questionnaires during the workshop, while others returned them individually at a later date. Students responded to the questionnaires and they were collected during the seminar. The result of the questionnaire consisted of responses including 
metaphors about the role of English teachers in the process of teaching and learning. Most respondents provided only one comparison. In case more than one metaphor was provided, they were all taken into account. Thereafter, the researcher reviewed the responses to identify metaphors.

\subsection{Data Analysis}

The data analysis followed the procedure created by Cameron et al. (1999, suggested in Wan et al., 2011) in which specific linguistic metaphors were identified and grouped under a specific title. Next, specific patterns of metaphors were identified. Data analysis involved four steps suggested by Wan et al. (2011) and Saban et al. (2007); (a) naming/ labeling, (b) sorting (clarification and elimination), (c) categorization, and (d) analyzing data. For each sentence, three elements were identified: the topic (e.g., the teacher), the vehicle (i.e., the term to which the topic is compared), and the ground (the relationship between the topic and the vehicle). The metaphor supplied by participants was coded and then put in specific tables. Next, based on the metaphor itself and the rationales participants provided, eight conceptual themes (categories) were generated. Interestingly, a number of the conceptual categories identified from respondents of this study were best categorised by similar theme outlined by Wan et al. (2011) and Saban et al. (2007).

Not all metaphors produced by students were analyzable and valid. Some students did not complete the task at all. Reasons given for noncompletion were not completed by students. However, one may assume that the point of the task might not have been clear for them.

\section{Results}

In this study, metaphor has been used as a tool to examine both teachers and students' conceptions of the role of English teachers in the process of teaching and learning. The task of using metaphors to explore ideas and conceptions was useful to promote reflection and discussion of the role of English teachers and to raise teachers' awareness about how their students perceive them. Eight conceptual categories have been introduced from the linguistic metaphors and example metaphors for each category are given in the results tables. The eight conceptual categories include: Teacher as devotee, Teacher as nurturer, Teachers as provider /Source of knowledge, Teacher as cultural transmitter/guide, Teacher as authority, Teacher as guider, Teacher as a friend, and Teacher as a nice beautiful soul. All participants expressed the same conceptual categories; still, they use different metaphors to express their views. An interesting feature of these results is that there are some parallel and overlaps of metaphors among different subjects.

For example, out of eighteen EFL teachers, the dominant conceptual metaphor is an English teacher is a devotee (e.g., silkworm, candle, bee, worker, 
sacrifice, and ladder). Interestingly none of the students' view teachers as devotees. Also, one that is significant is that an English teacher is a provider or source of knowledge (e.g., actor, forest bird, a muse, a bank). Others included an English teacher is a nurturer (e.g., mother, gardener) and an English teacher is a cultural transmitter (e.g., bridge, tour guide). Teachers as facilitators have been used by two teachers as combined with other metaphors (Table 1).

Table 1. Themes emerging from responses of teachers' metaphors about English teachers' roles (Number of Response: 18)

\begin{tabular}{|c|c|c|}
\hline $\begin{array}{l}\text { Conceptual } \\
\text { Categories } \\
\end{array}$ & $\begin{array}{l}\text { Metaphor } \\
\text { Examples }\end{array}$ & Justification/Elaboration \\
\hline Teacher as a devotee & $\begin{array}{l}\text { Candle (3) } \\
\\
\text { Bee } \\
\text { Worker } \\
\text { Sacrificer } \\
\text { Ladder }\end{array}$ & $\begin{array}{l}\text {-A teacher sacrificing himself/herself } \\
\text { for the sake of students. } \\
\text {-He helps in ending illiteracy through } \\
\text { too much effort. He burns himself for } \\
\text { others. } \\
\text {-He burns himself to give light to the } \\
\text { surroundings. } \\
\text {-The fruit of his/her effort is like } \\
\text { honey. } \\
\text {-He is not given what he deserves. } \\
\text {-S/he devotes all his/her efforts and } \\
\text { time for the sake of students. } \\
\text {-He/she helps students to climb up and } \\
\text { reach the top, while he remains at the } \\
\text { bottom all the time. }\end{array}$ \\
\hline Teacher as a nurturer & $\begin{array}{l}\text { Mother (2) } \\
\text { Gardener (2) }\end{array}$ & $\begin{array}{l}\text {-I see myself teaching them the first } \\
\text { steps of academic life. } \\
\text {-Always think of the best ways of } \\
\text { transforming scientific knowledge to } \\
\text { learners. } \\
\text {-Teachers plant seeds of truth and } \\
\text { wisdom inside their students. } \\
\text {-We do everything we can to ensure } \\
\text { that the seed we plant today will } \\
\text { blossom tomorrow. }\end{array}$ \\
\hline $\begin{array}{l}\text { Teachers as a provider } \\
\text { /Source of knowledge }\end{array}$ & $\begin{array}{l}\text { Forest bird } \\
\text { Muse } \\
\text { Bank }\end{array}$ & $\begin{array}{l}\text {-She/he has to put on the character of } \\
\text { the native speaker of English, ......... } \\
\text { has to imitate the accent in the best } \\
\text { possible way. } \\
\text {-He acts many roles while he teaches. } \\
\text { Sometimes, he smiles but he is not } \\
\text { happy... } \\
\text {-He is free to move into the realms of } \\
\text { four skills, picking from here and there } \\
\text { what suits the level of his students. } \\
\text {-An English teacher inspire his /her } \\
\text { students to be engaged in the process of } \\
\text { learning a language. }\end{array}$ \\
\hline
\end{tabular}




\begin{tabular}{|c|c|c|}
\hline & & $\mathrm{He} /$ she is the source of knowledge. \\
\hline $\begin{array}{l}\text { Teacher as a cultural } \\
\text { transmitter/guide }\end{array}$ & $\begin{array}{l}\text { Bridge } \\
\text { Tour guide }\end{array}$ & $\begin{array}{l}\text {-He/she is the link to learning the } \\
\text { universal language used all over the } \\
\text { world. } \\
\text { - He guides the students the right way. }\end{array}$ \\
\hline Teacher as an authority & Authority & -Students want that. \\
\hline
\end{tabular}

The description of teachers by second year group was the most interesting. Although they represent the same metaphorical themes, their use of metaphors were more nature-related elements. The most frequent conceptual category was teacher as a provider or source of knowledge (sun, cloud, river, sky, treasure, ocean, sea, water, forest, blood, Oxford Advanced learner dictionary, dictionary, book, mind, library). Others included an English teacher as a friend (e.g., friend, rose), an English teacher as a nurture (parents, member of my family, father), an English teacher as an authority (e.g., producer, drug, heaven, lion, Ezrail). A group of students described an English teacher as "a shining figure" (e.g., flower, moon, light, stars).

Table 2. Themes emerging from responses of second year students' metaphors about English teachers' roles (Number of Response: 45)

\begin{tabular}{|l|l|l|}
\hline Conceptual Categories & Metaphor Examples & Justification/Elaboration \\
\hline $\begin{array}{l}\text { Teacher as a provider/ } \\
\text { Source of knowledge }\end{array}$ & Sun (7) & $\begin{array}{l}\text {-They are full of all nice things. } \\
\text {-He always tries to give us light } \\
\text { for our future. } \\
\text {-They give us everything we } \\
\text { need } \\
\text {-They light our life. } \\
\text {-He/she gives different branches } \\
\text { of knowledge. } \\
\text {-They give us many } \\
\text { information. } \\
\text {-They give us light of study. } \\
\text { Treasure (3) }\end{array}$ \\
& $\begin{array}{l}\text {-Whatever they give is always } \\
\text { great. } \\
\text {-I can get from him/her every } \\
\text { kind of jewelry of English } \\
\text { language. }\end{array}$ \\
\hline
\end{tabular}




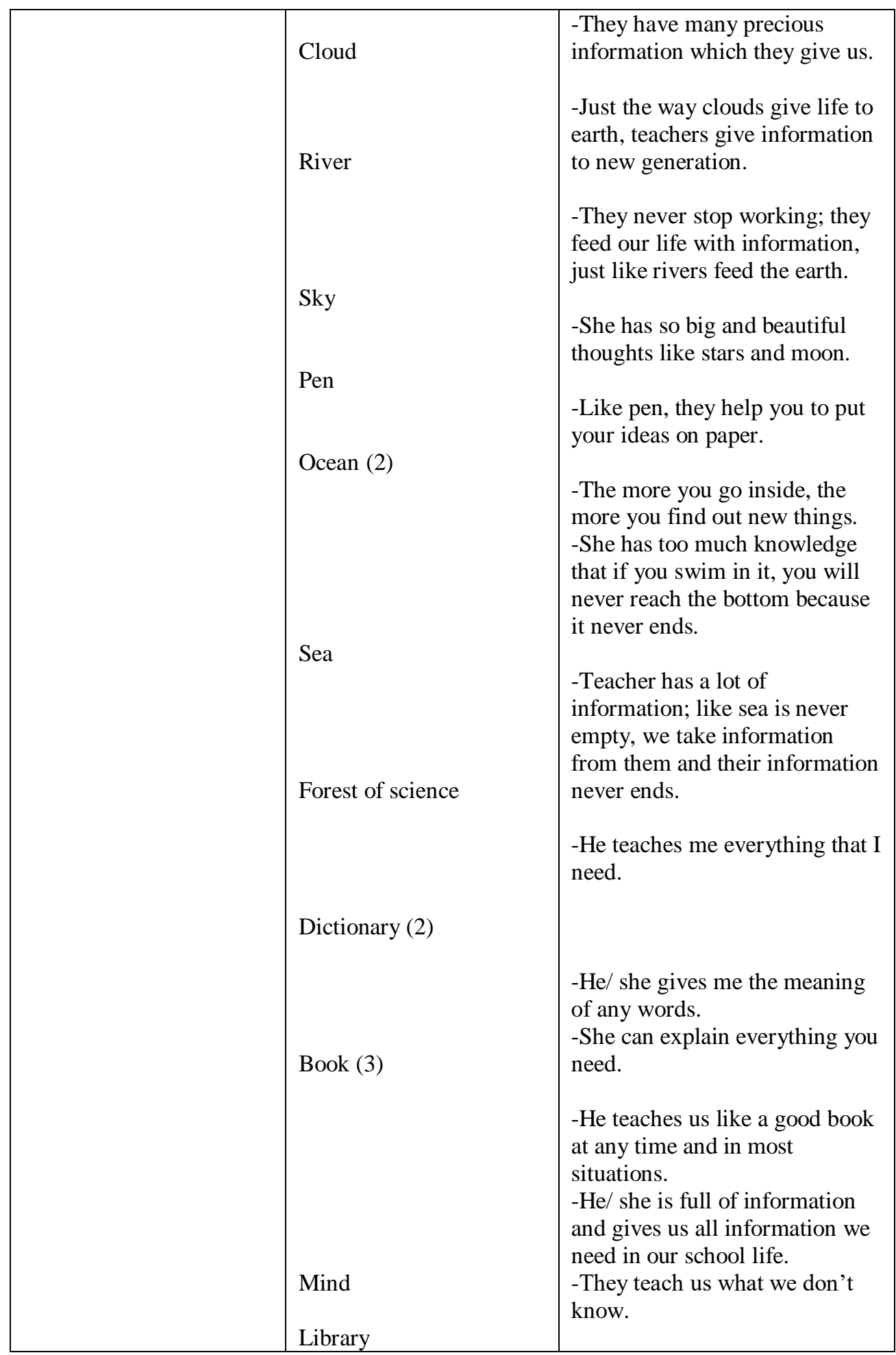




\begin{tabular}{|c|c|c|}
\hline & & $\begin{array}{l}\text {-They give us information we } \\
\text { need. } \\
\text {-They have information about } \\
\text { anything. }\end{array}$ \\
\hline Teacher as friend & $\begin{array}{l}\text { Friend (5) } \\
\text { Rose }\end{array}$ & $\begin{array}{l}\text {-Teacher is like a friend with } \\
\text { students. } \\
\text {-Anything I want I can tell } \\
\text { them. } \\
\text {-They are like friends. } \\
\text {-The way he/she deals with us is } \\
\text { like a friend. } \\
\text {-They are helpful and lead us on } \\
\text { the right way. } \\
\text {-She is like our friend, she is } \\
\text { always happy with a smiley } \\
\text { face. }\end{array}$ \\
\hline Teacher as nurturer & $\begin{array}{l}\text { Parents (4) } \\
\text { Father } \\
\text { Family member } \\
\text { Drug }\end{array}$ & $\begin{array}{l}\text {-They teach me. } \\
\text {-She teaches us other things that } \\
\text { real parents don't teach us. } \\
\text {-He/she will teach you } \\
\text { everything that you don't know } \\
\text { before. } \\
\text {-They educate us the best way. } \\
\text {-They work hard to make us to } \\
\text { be fluent students and treat us in } \\
\text { a good way. } \\
\text {-They defend and help us to } \\
\text { study and learn more. } \\
\text {-She can heal our injuries. }\end{array}$ \\
\hline Teacher as authority & $\begin{array}{l}\text { Lion } \\
\text { Ezrail } \\
\text { Goalkeeper }\end{array}$ & $\begin{array}{l}\text {-They are king like lion. } \\
\text {-If he does his work the best } \\
\text { way, our country will never fall } \\
\text { down or give up. }\end{array}$ \\
\hline $\begin{array}{l}\text { Teacher as a nice } \\
\text { beautiful soul }\end{array}$ & $\begin{array}{l}\text { Moon (2) } \\
\text { Light (2) } \\
\text { Stars(2) }\end{array}$ & $\begin{array}{l}\text {-She is lovely, smart, and } \\
\text { beautiful. } \\
\text {-He/she is beautiful and give a } \\
\text { perfect nice smell. } \\
\text {-She shines the class for us. } \\
\text {-She is nice and as the moon she } \\
\text { lightens the darkness and } \\
\text { brightens my life. } \\
\text {-She/he enlightens our life. } \\
\text {-We can learn and see life from } \\
\text { them. } \\
\text {-She always shines in the class. }\end{array}$ \\
\hline
\end{tabular}




\begin{tabular}{|l|l|l|}
\hline Heaven & $\begin{array}{l}\text {-She gives brightness to my life } \\
\text { for teaching me. } \\
\text {-We all want to go to heaven } \\
\text { and we all want to be like our } \\
\text { English teachers. }\end{array}$ \\
\hline
\end{tabular}

As for fourth year students, the teaching roles of EFL teachers were described mainly as provider or source of knowledge (e.g., light, sun, tree, rain, dictionary, treasure, book, machine, pen, Google, transmitter, etc.). Other important metaphorical themes are an English teacher as a guide (e.g., guider, wheel, huge ship, light, pathway) and an English teacher as a nurturer (e.g., father, parents). Only one student described an English teacher as an "authority" (e.g., wind).

Table 3. Themes emerging from responses of fourth year students' metaphors about English teachers' roles (Number of Response: 30 )

\begin{tabular}{|c|c|c|}
\hline Conceptual Categories & $\begin{array}{l}\text { Metaphor } \\
\text { Examples }\end{array}$ & Justification/Elaboration \\
\hline $\begin{array}{l}\text { Teacher as a provider } \\
\text { /source of knowledge }\end{array}$ & $\begin{array}{l}\text { Light } \\
\text { Sun } \\
\text { Tree } \\
\text { Rain } \\
\text { Dispenser of } \\
\text { science } \\
\text { Dictionary (2) } \\
\text { Book (3) } \\
\text { Treasure } \\
\text { Machine (3) } \\
\text { Pen } \\
\text { Google } \\
\text { Transmitter } \\
\text { Cook }\end{array}$ & $\begin{array}{l}\text {-They teach us an important language } \\
\text { in the world. } \\
\text {-They give light to the world. } \\
\text {-He gives you fruit of knowledge. } \\
\text { - His/her knowledge wets everything. } \\
\text {-They pour their sciences into our } \\
\text { empty dispenser of science. } \\
\text {-He/she teaches students how to learn } \\
\text { English and how to use new } \\
\text { vocabulary in English language. } \\
\text {-He has a lot of vocabulary. } \\
\text {-He is like a book full of culture and } \\
\text { information. } \\
\text {-She gives the knowledge. } \\
\text { - He/she is full of information. } \\
\text {-He provides students with a lot of } \\
\text { information. } \\
\text {-Teacher gives students best ideas. } \\
\text {-Teacher can invent everything } \\
\text { students want and create new things. } \\
\text {-He gives new ideas. } \\
\text {-They have information and give them } \\
\text { to us. } \\
\text {-I can search for information from } \\
\text { them. } \\
\text {-Transfers language information to } \\
\text { students. } \\
\text {-The teacher combines different } \\
\text { ingredients ... and put them in a plate } \\
\text { and gives it to students. }\end{array}$ \\
\hline
\end{tabular}




\begin{tabular}{|c|c|c|}
\hline & & $\begin{array}{l}\text {-Teacher collects various ideas in his } \\
\text { mind. }\end{array}$ \\
\hline Teacher as a guide & $\begin{array}{l}\text { Guide (3) } \\
\text { Wheel } \\
\text { Ship } \\
\text { Light } \\
\text { Pathway }\end{array}$ & $\begin{array}{l}\text {-He/ she show the right way for } \\
\text { students. } \\
\text {-He guides the students and paves the } \\
\text { way for the students to learn English } \\
\text { language. } \\
\text {-Teacher drives me to the goal. } \\
\text {-He makes me sail in his wide sea that } \\
\text { is full of knowledge. } \\
\text {-He/she guides students the right way. } \\
\text {-He leads students the right way along } \\
\text { with needed information and } \\
\text { knowledge. }\end{array}$ \\
\hline Teacher as a nurturer & $\begin{array}{l}\text { Father (2) } \\
\text { Parents }\end{array}$ & $\begin{array}{l}\text {-He educates students to be on the } \\
\text { right way of life. } \\
\text {-He doesn't make difference between } \\
\text { students as if they are his sons or } \\
\text { daughters. } \\
\text {-They teach students the new language } \\
\text { parents teach their children to speak. }\end{array}$ \\
\hline Teacher as an authority & Wind & $\begin{array}{l}\text {-They have power over students in } \\
\text { every aspect. }\end{array}$ \\
\hline
\end{tabular}

Table 4. Results summary

\begin{tabular}{|c|c|c|c|c|c|c|c|}
\hline$\#$ & Conceptual categories & Tea & & $\begin{array}{r}\mathrm{Sec} \\
\mathrm{S}\end{array}$ & $\begin{array}{l}\text { Year } \\
\text { ents }\end{array}$ & $\begin{array}{r}\text { Fou } \\
\mathrm{S}\end{array}$ & $\begin{array}{l}\text { Year } \\
\text { nts }\end{array}$ \\
\hline 1 & Teacher as a devotee & 7 & $39 \%$ & 0 & $0 \%$ & 0 & $0 \%$ \\
\hline 2 & Teacher as a nurturer & 4 & $22 \%$ & 7 & $16 \%$ & 3 & $10 \%$ \\
\hline 3 & $\begin{array}{l}\text { Teachers as a provider } \\
\text { /Source of knowledge }\end{array}$ & 4 & $22 \%$ & 25 & $56 \%$ & 19 & $63 \%$ \\
\hline 4 & $\begin{array}{c}\text { Teacher as a cultural } \\
\text { transmitter }\end{array}$ & 2 & $11 \%$ & 0 & $0 \%$ & 0 & $0 \%$ \\
\hline 5 & Teacher as an authority & 1 & $6 \%$ & 3 & $7 \%$ & 1 & $3 \%$ \\
\hline 6 & Teacher as a guide & 0 & $0 \%$ & 0 & $0 \%$ & 7 & $23 \%$ \\
\hline 7 & Teacher as a friend & 0 & $0 \%$ & 6 & $13 \%$ & 0 & $0 \%$ \\
\hline 8 & $\begin{array}{c}\text { Teacher as a nice } \\
\text { beautiful soul }\end{array}$ & 0 & $0 \%$ & 9 & $20 \%$ & 0 & $0 \%$ \\
\hline
\end{tabular}

\section{Discussion}

As the findings of this study show, the metaphors generated by the second and fourth year students suggest no significant differences. They both express the same conceptual category teacher as a provider/ source of knowledge and teacher as a nurturer. Apart from second year students, the conceptual category teacher as a guide has been commonly used by fourth year students. The findings of this study also suggested subtle differences between students' and teachers' beliefs. The difference occurs primarily when teachers portrayed themselves as devotees. According to this theme, teachers give 
themselves a negative role. For example, some teachers used the term 'candle' to conceptualize his/her role as a teacher using rationales such as 'a teacher sacrifices himself/herself for the sake of students,' 'he burns himself for others,' 'he burns himself to give light to the surroundings.' A sacrifice is something one willingly does in exchange for something better. Looking back at the description of teachers, it can be noticed that teachers do not convey a positive connotation of the term 'sacrificing.' They think of themselves as victims rather than sacrificers. For example, one of the teachers used the word 'worker' to describe himself/herself as a victimized worker who does not get what he/she deserves. Another teacher describes his/her role as being significant for the future of students and marginal for himself/herself by stating "he/she helps students to climb up and reach the top, while he/she remains at the bottom all the time." Thus, this conceptualization on the side of teachers may affect the process of teaching because teachers need to think positively of their roles and convey positive messages throughout their interaction with students to be able to motivate students.

Looking at the results summary table of the metaphor analysis, it is significant to note that teachers and students share different beliefs about the role of teachers. For example, students consider the teaching and learning process as a teacher-centered approach in which they think of teachers as the dominant source of information. For example, $56 \%$ of second year students and $63 \%$ of fourth year students perceived the role of teachers as the source of knowledge or provider, while only $22 \%$ of teacher perceived themselves as the source of knowledge or provider. According to Emaliana (2017), in teacher-centered learning, teacher plays an important role in the learning process. Teachers are information providers or evaluator to monitor students to get the right answers, yet students are viewed as learners who passively receive information. $23 \%$ of fourth year students, who may represent the number of students with sufficient level of English language, perceived the role of an English teacher as a "guide" which pedagogically reflects their preferences of student-centered learning, while $0 \%$ of second year students used this metaphor. This may indicate the fact that due to the low English level of second year students, they lack the confidence to have an active role when participating in the learning and teaching process while their teachers only play the role of a facilitator who help guide the students to manage their activities and direct their learning. This indicates that using metaphor as an analytical tool about beliefs and perceptions is significant in revealing students' needs and expectations before planning approaches in teaching and learning English language. To enable students to succeed in learning English as Foreign Language (EFL), teachers should either aim to change students' perception towards what teachers think could be the best English language 
teaching and learning approach for them or should plan the English language teaching and learning approach based on the students' needs and expectations. $22 \%$ of teachers, $16 \%$ of second year students, and $10 \%$ of fourth year students perceived English teachers' roles as a 'nurturer.' Only one teacher and three students perceived teachers' role as an 'authority'. Moreover, $13 \%$ of second year students perceived an English teacher as a 'friend' and $20 \%$ as a 'beautiful soul.' Second year students were too emotional and imaginative in their use of linguistic metaphors. Many of the metaphors used by students showed their natural trend in using natural elements such as sun, ocean, cloud, river, sky, and sea to describe their teachers' roles. This conceptualization of teachers is of great significance in the sense that it gives the impression that teachers deal with students as humans in which they take into considerations their needs, interests, moods, and social backgrounds. For example:

'An English teacher is a cloud because just the way clouds give life to earth, teachers give information to new generation.'

'An English teacher is a sun because they give us everything we need.'

'An English teacher is a river because they never stop working; they feed our life with information, just like rivers feed the earth.'

Therefore, such uses of metaphors indicate that students' emotional needs should also be taken into consideration when planning the teaching and learning methodologies. The classroom should not only be a place where students receive knowledge and learn but should also reflect a pleasant, secure, and warm atmosphere for students and teachers. Thus, it is important for teachers to review their teaching strategies and choose the best type of pedagogy that might be appropriate for their classes based on their clear interaction with students.

Interestingly, most of the second year students use the pronoun 'she' in the entailments of the conceptual category 'teacher a beautiful soul.' This study is not designed to show the relationship between students and teachers' genders and their perception of the teachers' roles during the teaching and learning process. However, it will be interesting to investigate if the gender of students and teachers impact the types of metaphors that are used to describe the teachers' roles. In their study, Nikitina et al. (2008) showed no differences between male and female students attitudes (overtly positive vs. overtly negative) towards language teachers. The results showed that female students outnumbered male students in metaphors such as 'teacher as a guide,' 'teacher as a nurturer,' 'teacher as knower' while male students outnumber female students in their perception of 'teachers as provider of knowledge,' 'teacher as someone hardworking,' and 'someone that is good-hearted.' Female and male students had different views regarding two categories: teacher as a provider of knowledge and teacher as a knower. Male students prefer to view their 
teachers with the traditional teaching approach as the dominant source of knowledge rather that the person to communicate with. While the female teachers conceptualized their teachers as 'knower' which showed that they considered their teachers as not only the owner of knowledge but also as a person who meet their emotional needs by giving them the feeling of security and comfort with the nurturer role. In another study conducted by Eraslan and Asmali (2017), they sought answers as to whether metaphors generated in their studies were gender based or not.

Thus, one may conclude that using metaphor as an exploratory tool could help in revealing how students think of their teachers and how teachers think of themselves. Thus, this may help teachers to adapt to the roles which are expected from them. For example, according to students' conceptualizations of an English teacher, a teacher should have a motherly love with their students, be knowledgeable about their subject, be flexible, be an effective communicator, cares about humanity in general and when looking at students only sees the soul of a human being, be friendly, be motivated, and radiate their interest to his subject.

Most importantly, teachers need to bear in mind that moving towards a student-centered approach which is more effective, when students maintain that teacher-centered expectation, may raise problems. Thus, it would be useful if teachers try to create a well-balanced educational situation by combining both approaches and consequently students could enjoy the positive results of both approaches.

\section{Conclusion}

This study has led to several conclusions that highlight some implications for teaching approaches in education and to ideas for further investigations. First, metaphor can be a very useful tool to investigate the mindset of teachers and students and find out the way each party views the role of teachers in the process of learning so as to enhance self-awareness and professional development. Moreover, it provides information for understanding teachers' and students' philosophical dimensions, roles, and practices in the process of teaching and learning. Teachers' use of metaphor described their experiences in the process of teaching and learning which according to Provenzo, McCloskey, Kottkamp and Cohn (1989) helps them to evaluate themselves and identify what is difficult for them to be described in other ways. Thus, teachers may not be aware of the way that they view themselves but when it comes to asking them to express themselves using metaphors, they may start realizing their roles and consequently relating to the reasons that lead them to assess their role and performance as well as to find solutions when problems arise. Second, teachers need to know how their 
students perceive them to adjust their teaching style, their teaching materials, and the classroom environment.

Lastly, this investigation shows a clear relationship between teachers' and students' metaphors and helps to relate particular sets of metaphors to different types of classroom behaviour and different approaches to learning. However, in the process of teaching and learning, it seems worthwhile to explore both parties' reactions to each other's perspectives, how they affect the pedagogical process, how they may combine or complement each other, and how they may change over time. This could be done by exploring what happens to teachers' roles in the context of the English classes when teachers compare their metaphors to their students and see how the teachers will make changes to their teaching approaches. This was one of the key limitations of this study. Another key limitation is that the results of this study cannot be generalized due to the small sample, especially of teachers. As stated before, this study is useful for teachers, curriculum designers, and researchers. Researchers may carry out comprehensive studies on using metaphor as an investigating tool to understand both students and teachers' perceptions of the teachers' roles. Thus, their results can help develop comprehensive and inclusive methods of teaching. Larger samples with variables such as gender, age, different locations, and proficiency of participants should be taken into consideration during future studies.

\section{References :}

1. Akbari, M. (2013). Metaphors about EFL Teachers' Roles: A Case of Iranian Non- English-Major Students. International Journal of English Language \& Translation Studies, 1(2), 100-112.

2. Aristotle (1965). Poetics. Blackwell, Oxford.

3. Black, M. (1962). Models and Metaphors. NY: Cornell University Press.

4. Block, D. (1992). Metaphors we teach and learn by. Prospect, 7(3), 42-55.

5. Cameron, L. \& Low, G. (1999). Researching and Applying Metaphor. Cambridge: Cambridge University Press.

6. Cameron, L. \& Deignan, A. (2006). The emergence of metaphor in discourse. Applied Linguistics, 27(4), 671-690.

7. Cortazzi, M. \& Jin, L. (1999). Bridges to learning: metaphors of teaching, learning, and language. In: Cameron, L., Low, G.D. (Eds.), Researching and Applying Metaphor (pp. 149-176). Cambridge: Cambridge University Press.

8. Ellis, R. \& Barkhuizen, G. (2005). Analysing learner language. Oxford: Oxford University Press. 
9. Emaliana, I. (2017). Teacher-centered or Student-centered Learning Approach to Promote English-Major Students. International Refereed \& Indexed Journal of English Language \& Translation Studies, 1(2), 100-112.

10. Eraslan, A. \& Asmali, M. (2017). From Students' Perspectives: EFL Learners' Metaphors about English Instructors in Turkey. Eğitim Fakültesi Dergisi ,30 (2), 419-442.

11. Gibbs, R.W. (1994). The Poetics of Mind. New York: Cambridge University Press.

12. Koroglu, Z.C. \& Ekici, G. (2016). English Language Teacher Candidates' Perceptions of Language Teachers: A Metaphor Study. International Journal of Languages' Education and Teaching, 5(2), 387-398.

13. Kovecses, Z. (2002). Metaphor: A Practical Introduction. Oxford: Oxford University Press.

14. Kövecses, Z. (2005). Metaphor in culture: Universality and variation. Cambridge, England: Cambridge University Press.

15. Lakoff, G. \& Johnson, M. (1980). Metaphors We Live By. Chicago and London: The University of Chicago Press.

16. Lin, W., Shein, P.P. \& Yang, S.C. (2012). Exploring personal EFL teaching metaphors in pre-service teacher education. English Teaching: Practice and Critique, 11, 183-199.

17. Marchant, G. J. (1992). A teacher is like a...: Using simile lists to explore personal metaphors. Language and Education, 6(1), 33-45.

18. McGlone, M. (2007). What is The Explanatory Value of a Conceptual Metaphor? Language and Communication,27, 109-126.

19. McGrath, I. (2006). Teachers' and learners' images for coursebooks. ELT Journal, 60(2), 171-180.

20. Munby, H. (1986). Metaphor in the thinking of teachers: an exploratory study. Journal of Curriculum Studies, 18 (2), 197-209.

21. Nikitina, L. \& Furouka, F. (2008). “A Language Teacher is Like...”: Examining Malaysian Students' Perceptions of Language Teachers through Metaphor Analysis. Centre for Language Studies National, 5 (2), 192-205.

22. Provenzo, E.F., McCloskey, G.N., Kottkamp, R.B. \& Cohn, M.M. (1989). Metaphor and meaning in the language of teachers. Teachers College Record. 90. 551-573.

23. Richards, I.A. (1936). The Philosophy of Rhetoric. Oxford University Press: Oxford.

24. Saban, A., Kocbeker, B.N. \& Saban, A. (2007). Prospective Teachers' Conceptions of Teaching and Learning. 
25. Villamil, O.S. \& de Guerrero, M.C.M. (2005). Constructing theoretical notions of L2 writing through metaphor conceptualization. In: Bartels, N. (Ed.), Applied Linguistics in Language Teacher Education (pp. 7990). New York: Springer.

26. Wan, W., Low, G.D \& Li, M. (2011). From Students' and teachers' perspectives: Metaphor analysis of beliefs about EFL teachers' roles. System 39, 403-415.

27. Wertsch, J. (1991). Voices of the Mind: A Sociocultural Approach to Mediated Action. Cambridge: Harvard University Press.

28. Xiong, H., Li, L. \& Qu, Y. (2015). Exploring EFL Teachers' Cognitive Models Through Metaphor Analysis. SAGE, Open, 5(4), 1-11. 